22. Hamburger, M.: The role of thyroid and growth hormones in neurogenesis. Current Top. Develop. Biol., 4: 109 (1969).

23. Hopkins, P. S., and Thorburn, G. D.: Placental permeability to maternal thyroxine in sheep. J. Endocrinol., 49: 549 (1971).

24. Hopkins, P. S., and Thorburn, G. D.: The effects of foetal thyroidectomy on the development of the ovine fetus. $J$. Endocrinol., 54: 55 (1972).

25. Kerr, G. R., Tyson, I. B., Allen, J. R., Wallace, J. H., and Scheffler, G.: Deficiency of thyroid hormone and development of the fetal Rhesus monkey. I. Effect on physical growth, skeletal maturation and biochemical measures of thyroid function. Biol. Neonate, 21: 282 (1972).

26. Klein, A. H., Meltzer, S., and Kenny, F. M.: Improved prognosis in congenital hypothyroidism treated before three months. J. Pediat., 81: 912 (1972).

27. Liggins, G. C., and Kennedy, F. C.: Effects of electrocoagulation on the foetal lamb hypophysis on growth and development. J. Endocrinol., 40: 371 (1968).

28. Lowry, O. H., Rosebrough, N. J., Farr, A. L., and Randall, R. J.: Protein measurement with the Folin phenol reagent. J. Biol. Chem., 198: 265 (1951).

29. Muzzo, S. J., and Brasel, J.: Neonatal hypothyroidism and DNA synthesis in rat cerebellum. Program of the 55 th Meeting of the Endocrine Society, June 1973, p. A155 (Abstract 214).

30. Myant $N$ B. On the possible role of the thyroid in the control of the development of the mammalian brain. Biol. Neonate, $9: 148$ (1966).

31. Omori, K., Oh, W., Emmanouilides, G. C., Erenberg, A., and Hobel, C. J.: Intrauterine somatic growth in sheep. In preparation.

32. Patel, A. J., and Balazs, R.: Effect of thyroid hormone on metabolic compartmentation in the developing rat brain. Biochem. J., 121: 469 (1971).

33. Redding, R. A., Douglas, W. H. J., and Stein, M.: Thyroid hormone influence upon lung surfactant metabolism. Science, 175: 994 (1972).

Copyright (c) 1974 International Pediatric Research Foundation, Inc.
34. Reichlin, S., Martin, J. B., Boshans, R. L., Schalch, D. S., Pierce, J. G., and Bollinger, J.: Measurement of TSH in plasma and pituitary of the rat by radioimmunoassay utilizing bovine TSH Effect of thyroidectomy or thyroxine administration on plasma TSH levels. Endocrinology, $87: 1022$ (1970).

35. Sokoloff, L: Action of thyroid hormones and cerebral development. Amer. J. Dis. Child., 114: 498 (1967).

36. Stein, R. A., Slauson, V., and Mead, J. F.: Gas-liquid chromatog raphy of fatty acids and derivatives. In: G. V. Marinetti: Lipid Chromatographic Analysis, pp. 361 (Marcel Dekker, New York, 1967).

37. Szijou, I., Kalbermann, L. E., and Gomez, C. J.: Hormonal regulation of brain development. IV. Effect of neonatal thyroidectomy upon incorporation in vivo of L- $\left({ }^{3} \mathrm{H}\right)$ phenylalanine in proteins of developing rat cerebral tissues and pituitary gland Brain Res., 27: 309 (1971).

38. Walravens, P., and Chase, H. P. Influence of thyroid on formation of myelin lipids. J. Neurochem., 16: 1477 (1969).

39. Webb, J. M.: A sensitive method for the determination of ribonucleic acid in tissue and microorganisms. J. Biol. Chem., 221: 635 (1956)

40. Wu, B. Kikkawa, Y., Orzalesi, M. M., Motoyama, E. K., Kaibera, M., Zingas, C. J., and Cook, D. D.: Accelerated maturation of fetal rabbit lungs by thy roxine. Physiologist, 14: 253 (1971).

41. We are grateful to Donald Harris, Robert Lam, Sherri Ho, and Bonnie Privett for technical assistance and to Sharyn Shaw for preparation of the manuscript.

42. This research was supported by United States Public Health Service Grants nos. HD-04720 and NB-06938 from the National Institutes of Child Health and Human Development and the National Institute of Neurological Diseases and Blindness.

43. Requests for reprints should be addressed to: D. A. Fisher, M.D., Harbor General Hospital, 1000 W. Carson St., Torrance, Calif. 90509.

44. Accepted for publication April 26, 1974.

Printed in U.S.A.

\title{
Fibrin-stabilizing Factor (Factor XIII) in the Fetus and the Newborn Infant
}

\author{
P. HENRIKSSON, U. HEDNER, I. M. NILSSON, J. BOEHM, B. ROBERTSON, AND L. LORAND ${ }^{(30)}$ \\ Coagulation Laboratory, University of Lund, Allmänna sjukhuset, Malmö, Sweden, Evanston Hospital and \\ Department of Biochemistry and Molecular Biology, Northwestern University, Evanston, Illinois, USA
}

\section{Extract}

Using a fluorescent method based on the ability of the thrombin and calcium-activated fibrin-stabilizing factor (factor XIII) to incorporate dansyl cadaverine into casein, measurements were made in plasma samples from 52 healthy neonates and 25 fetuses between the 17th and 24th gestational weeks. Forty healthy adults and 63 samples from pregnant women were used as controls. The measured values ranged from 3 to 21 units/ml of plasma for neonates and 1 to 14 for fetuses, compared with 7 to 42 for the adult normal and 3 to 15 for the pregnant women populations.

\section{Speculation}

It is conceivable that the relatively low fibrin-stabilizing factor activity during fetal life and immediately after birth, corresponding, respectively, to mean values of about 0.25 and
0.5 of that found in normal adults, may afford some safeguard against lasting coagulation damage.

In recent years much interest has been focused on fibrin-stabilizing factor (FSF or factor XIII), the plasma zymogen of the transamidating enzyme responsible for the covalent cross-linking of fibrin molecules during clotting. Its chemical properties (for review see Reference 8) and variations of the plasma levels of the factor in different pathologic conditions have been the subject of several studies (e.g., 11, $13,18,19,22)$. For newborn infants, some authors reported low values $(1,3,7,23)$, whereas others have found normal adult levels $(6,14,17,21,24)$. However, all of these investigations were carried out with bioassays, such as differential clot solubilities, which from the quantitative point of view are of questionable reliability. 
A method based on the ability of the thrombin and calcium ion-activated factor XIII to incorporate a fluorescent amine (dansyl cadaverine) into casein has already been employed successfully $(9,10)$ for the quantitative evaluation of the mode of inheritance of the factor XIII genetic deficiency disease. In the present study, determinations were made with the use of this method on 52 healthy and 36 sick neonates and also in 25 fetuses obtained by legal abortion. Forty healthy adults and 63 samples from pregnant women were used as controls.

\section{MATERIALS AND METHODS}

\section{CLINICAL MATERIAL}

Fifty-two (45 from Malmö, 7 from Evanston) apparently healthy full term neonates were studied from normal pregnancies and vaginal delivery after 38-42 weeks of gestation. The Malmö material also included 25 fetuses obtained by induced abortion; mothers were healthy and their pregnancies were terminated on sociomedical grounds. The fetuses were removed by abdominal hysterotomy between the 17 th and 24 th gestational weeks. Crown-heel lengths measured between 17 and $30 \mathrm{~cm}$. Informed consent was obtained in accord with the Helsinki Declaration. The 36 sick newborns from Malmö comprised 10 with hyaline membrane disease (respiratory distress syndrome) and 26 with other neonatal disorders (mixed group).

\section{COLLECTION OF BLOOD}

Blood was drawn into plastic syringe by puncture of a cubital or a scalp vein. The technique described by Ekelund et al. (4) was used in the fetuses. Plasma was prepared as described previously (12) and was stored in plastic tubes at $-70^{\circ}$. In the neonates from Evanston cord blood was obtained from the freely flowing placental end of the cord before delivery of placenta. In the sick newborn infants blood specimens were obtained $2-24 \mathrm{hr}$ after delivery from an indwelling plastic catheter inserted in one of the umbilical arteries for therapeutic and diagnostic reasons.

\section{DETERMINATION OF FIBRIN-STABILIZING FACTOR}

A slight modification of the method described by Lorand $e t$ al. (10) was used; otherwise, unless indicated, volumes and conditions were those given in Table II of Reference 10. After "desensitizing" the fibrinogen in plasma by heating at $56^{\circ}$ for $4 \mathrm{~min}$ in the presence of glycerol $(50 \%)$ followed by rapid cooling, thrombin (topostasin, $25 \mathrm{NIH}$ units in the system (25)) and calcium chloride ( $3 \mathrm{mM}$ ) were added in order to allow activation of FSF. Dithiothreitol $(0.2 \mathrm{M})$ was used as a reducing agent. The incorporation reaction was started by admixing of monodansyl cadaverine (26) (2 $\mathrm{mM}$ in Trischloride, $\mathrm{pH} 7.5)$ and $3 \%$ casein. The reaction was terminated by addition of $10 \%$ trichloroacetic acid. The protein precipitate was then washed repeatedly in ethanol-ether $(1 / 1)$. After drying at room temperature, the precipitate was solubilized by digestion with $0.5 \mathrm{ml}$ trypsin (Trypure (27), 25 Anson units/g or $0.05 \mathrm{mg}$, in $0.1 \%$ ammonium bicarbonate buffer, pH 7.9) for 12 hr. Finally a mixture containing Tris-HCl buffer $(0.05 \mathrm{M}, \mathrm{pH} 8.0)$, urea $(8 \mathrm{M})$, and sodium dodecyl sulfate $(0.5 \%)$ was added. The fluorescence intensity of the solution was read against a $4 \mathrm{mM}$ monodansyl cadaverine standard and data are given in terms of this latter by expressing rate of amine incorporation as FSF units per milliliter of citrated plasma according to the formula given by Lorand et al. (10). A minor volume correction had to be made to account for dilution by the addition of trypsin.

\section{RESULTS}

\section{NORMAL ADULTS}

In 22 apparently healthy nonpregnant women aged 18-40 years, the level of fibrin-stabilizing factor was found to vary between 11 and 35 units/ml (mean 21 FSF units/ml plasma, $\mathrm{SD} \pm 6.6)$ and in 18 healthy men aged $25-45$ years, between 16 and 32 units (mean $22 \mathrm{FSF}$ units/ml plasma, SD \pm 4.3 ). No significant sex difference was found $(P>0.05)$. The mean of the whole adult material was $21 \mathrm{FSF}$ units/ml plasma (SD \pm 5.6 ), in agreement with earlier reports with this method (9). Values for pregnant women appear to be lower (Fig. 1).

\section{FULL TERM NEWBORNS AND FETUSES}

Values for fibrin-stabilizing factor in neonates from Malmö ranged from 6 to 21 units/ml plasma (mean 11 FSF units/ml plasma, SD \pm 3.4 ). In the 25 fetuses, the results fell between 1 and 14 units/ml plasma (mean $5 \mathrm{FSF}$ units/ml plasma, SD \pm 3.5). The difference between the fetal and the newborn levels was statistically significant $(P<0.001)$, as was also the difference between the neonatal and the adult material $(P<$ $0.001)$. In the group of seven neonates from Evanston the FSF levels ranged only from 3 to 6 units/ml plasma (mean 5 FSF units/ml plasma).

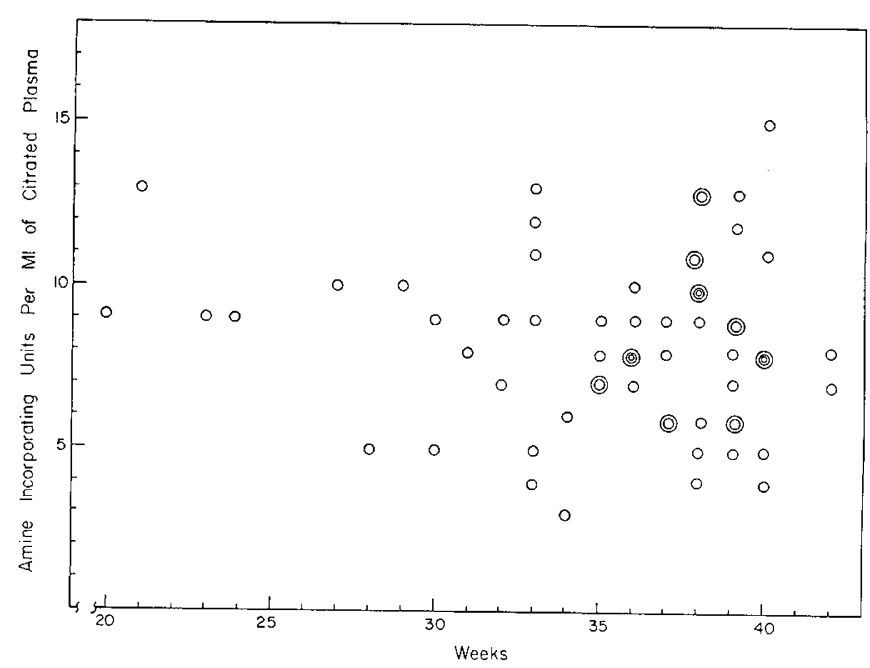

Fig. 1. Fibrin-stabilizing factor (factor XIII) values in plasma (ordinate) during various stages (abscissa) of pregnancy.

Table 1. Comparative data for fibrin stabilizing factor (factor XIII) using method described by Lorand et al. (10)

\begin{tabular}{|c|c|c|c|c|c|}
\hline \multirow[b]{2}{*}{ Subjects } & \multirow[b]{2}{*}{ Source } & \multirow{2}{*}{$\begin{array}{l}\text { No. } \\
\text { tested }\end{array}$} & \multicolumn{3}{|c|}{ Units/ml plasma } \\
\hline & & & Range & Mean & $\pm \mathrm{SD}$ \\
\hline Full term neonates & Malmö & 45 & $6-21$ & 11 & 3.4 \\
\hline Sick neonates & Evanston & 7 & $3-6$ & 5 & \\
\hline $\operatorname{RDS}^{1}$ & & 10 & $7-12$ & 8.5 & 1.9 \\
\hline Mixed group & & 26 & $3-24$ & 10.6 & 4.7 \\
\hline Fetus $^{2}$ & Malmö & 25 & $1-14$ & 5 & 3.5 \\
\hline \multirow[t]{2}{*}{ Adult controls } & Malmö & 40 & $11-35$ & 21 & 5.6 \\
\hline & Literature $^{3}$ & 72 & $7-42$ & 19 & 5.5 \\
\hline $\begin{array}{l}\text { Heterozygotes of hered- } \\
\text { itary deficiency }\end{array}$ & Literature $^{3}$ & 13 & $5-18$ & 12 & 3.3 \\
\hline Homozygote deficients & Literature $^{3}$ & 7 & & 0.2 & 0.1 \\
\hline
\end{tabular}

'Respiratory distress syndrome.

${ }^{2}$ No correlation with gestational age $(17-24$ weeks) could be detected.

${ }^{3}$ Literature values from Lorand et al. (9). 


\section{SICK NEWBORNS}

Values for fibrin-stabilizing factor were 7-12 units/ml plasma (mean 8.5; SD \pm 1.9 ) for the 10 neonates with respiratory distress syndrome (gestational age of 29-40 weeks), and 3-24 units/ml plasma (mean 10.6; SD \pm 4.7 ) for the 26 infants (gestational age of 26-40 weeks) with other neonatal disorders. There was no significant difference $(P>$ $0.05)$ between these two groups.

Our results to date are summarized in Table 1. For purposes of comparison included in the table are literature values obtained by the same method for 72 control individuals, for 7 homozygote hemorrhagic patients afflicted with the hereditary deficiency of total absence of functional fibrin stabilizing factor; and for 13 individuals, parents of these patients, classified as heterozygotes for this deficiency trait (9). No one in the latter group showed a noticeable hemorrhagic tendency. It is interesting to note that mean values for fibrin-stabilizing factor in the plasma of full term neonates are similar to those found in the adult heterozygote group. A number of newborn and fetal samples yielded results approximating the homozygotic deficiency state.

\section{DISCUSSION}

Zuch et al. (24) sought to explain apparent low values of fibrin-stabilizing factor in terms of a lower concentration of sulfhydryl groups in plasma, due perhaps to a not fully developed liver function in neonates. The assays used in our studies did include a sufficiently high concentration of dithiothreitol so as to measure the zymogen which could maximally be activated by thrombin and calcium ions. Inasmuch as the values in neonates were still significantly lower than those in adults, some other explanation must be found. We are inclined to think that there may be a mechanism which somehow regulates the concentration of fibrin-stabilizing factor in plasma so as to maintain the possible physiologic advantage seemingly tilted towards fibrinolysis during infancy as suggested by Ekelund et al. $(4,5)$. According to this concept, neonates would require an added protection against fibrin deposits and this would be achieved by a lowering of the concentration of factors which promote clotting (e.g., prothrombin) and by a higher than adult concentration of the components participating in lysis (e.g., plasminogen). Fibrin-stabilizing factor should fall in the former category because its functioning leads to a highly elastic clot structure $(8,16)$ which is very resistant to lysis. It is possible that the relatively low FSF activity during fetal life and immediately after birth, coupled with low values of other clotting factors and high values of fibrinolytic agents, can afford some extra safeguard against permanent damage caused by excessive coagulation. It might be mentioned that Ambrus. et al. $(1,2)$ suggested that there might be a relation between high levels of FSF and incidence of hyaline membrane in preterm babies. As seen in Table 1, our results to date do not seem to bear out this conclusion.

Also, it may be mentioned that postnatal studies on 20 normal babies indicate that adult levels of FSF (range of $13-30$ units $/ \mathrm{ml}$ plasma) have been achieved by about 3 weeks of age.

\section{CONCLUSION}

Functional factor XIII levels in plasma are significantly reduced during fetal life and in neonates (measured immediately after birth), in comparison with values found in the normal adult population. Hitherto, no significant difference could be found between healthy and sick neonates, although the latter group included 10 infants with hyaline membrane disease.

\section{REFERENCES AND NOTES}

1. Ambrus, C. M., Ambrus, J. L., Niswander, K. R., Weintraub, D. H. Bross, I. D. J., and Lassman, H. B.: Changes in fibrin-stabilizing factor levels in relation to maternal hemorrhage and neonatal disease. Pediat. Res., 4: 82 (1970).

2. Ambrus, C. M., Ambrus, J. L., Weintraub, D. H., Foote, R. J., Courey, N. G., and Niswander, K. R.: Thrombolytic therapy in hyaline membrane disease. Thromb. Diath. Haemorrh. Suppl., 47: 269 (1971).

3. Bouhasin, J. D., and Altay, C.: Factor XIII deficiency: Concentrations in relatives of patients and in normal infants. J. Pediat., 72 : 336 (1968).

4. Ekelund, H., Hedner, U., and Astedt, B.: Fibrinolysis in human foetuses. Acta Paediat. Scand., 59: 369 (1970).

5. Ekelund, H. Hedner, U., and Nilsson, I. M.: Fibrinolysis in newborns. Acta Paediat. Scand., 59: 33 (1970).

6. Fischer, S., Schwartz, M., Gottlieb, A., Ben Yoseph, N., and Shapiro, S.: Fibrinolysis, fibrinogen and factor XIII in newborn infants. Thromb. Diath. Haemorrh., 20:541 (1968).

7. Künzer, W. and Lütgemeier, J.: Zur entwicklungsbedingten Abhängigkeit des Plasmagehaltes an Fibrin-stabilisierendem Faktor (FSF). Ann. Paediat. 204: 232 (1965)

8. Lorand, L.: Fibrinoligase: The fibrin-stabilizing factor system of blood plasma. Ann. N. Y. Acad. Sci., 202: 6 (1972).

9. Lorand, Urayama, T., Atencio, A. C., and Hsia, D. Y-Y. Inheritance of deficiency of fibrin stabilizing factor (Factor XIII). Amer. J. Human Gen., 22: 89 (1970).

10. Lorand, L., Urayama, T., de Kiewiet, J. W. C., and Nossel, H. L. Diagnostic and genetic studies on fibrin-stabilizing factor with new assay based on amine incorporation. J. Clin. Invest., 48 : 1054 (1969).

11. Losowsky, M.S., and Walls, W. D.: Abnormal fibrin stabilization in renal failure. Thromb. Diath. Haemorrh., 22: 216 (1969).

12. Nilsson, I. M., Blombäck, M., and von Francken, I.: On an inherited autosomal haemorrhagic diathesis with antihaemophilic globulin (AHG) deficiency and prolonged bleeding time. Acta Med. Scand., 159: 35 (1957).

13. Nussbaum, M., and Morse, B. S.: Plasma fibrin stabilizing factor activity in various diseases. Blood, 23: 669 (1964).

14. Oehme, J.: Über die physiologischen Grundlagen der Blutstillung Neugeborener. Mschr. Kinderheilk., 112: 447 (1964).

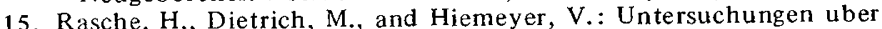
die Faktor XIII-Aktivität im Plasma bei akuter Leukämie (F XIII activity in leucemia). Klin. Wochenschr., 50: 1017 (1972).

16. Roberts, W. W., Lorand, L., and Mockros, L.: Viscoelastic properties of fibrin clots. Biorheology, 10:29 (1973).

17. Schettini, F Lattanzi, E., Violante, N., and Rana, N.: Il fattore XIII (Fibrin stabilizing factor) del neonato immaturo. Boll. Soc. Ital. Biol. Sper., 42: 924 (1966)

18. Ströder, J.: Über den fibrinstabilisierenden Faktor (FSF) in den verschiedenen Lebensabschnitten und bei bestimmten Krankheiten des Kindes. Ann. Paediat., 203: 393 (1964).

19. Ströder, J.: Reduction of fibrin stabilizing factor (FSF) in thrombocytopenia in childhood. Ann. Paediat., 205: 438 (1965).

20. Ströder, J.: Über fibrinstabilisierenden Faktor in den verschiedenen Lebensabschnitten. Mschr. Kind erheilk., 113: 293 (1965).

21. Violante, N. Paganetti, G., Lattanzi, E., and Schettini, F.: Il fattore XIII (fibrin stabilizing factor) nel neonato a terminale e nel lattante. Boll. Soc. Ital. Biol. Sper., 43: 535 (1967).

22. Walls, W. D., and Losowsky, M. S.: Plasma fibrin stabilizing factor (F.S.F.) activity in normal subjects and patients with chronic liver disease. Thromb. Diath. Haemorrh., 21: 134 (1969).

23. Yamada, Z.: The relationship between plasmin activity and the activity of factor XIII in the neonatal period. Acta Paediat. Jap. Engl. Ed., 13: 38 (1971).

24. Zuch, A., Buluk, K., Rudobielska, M., and Zwierzowa, W.: Variability of actual and potential fibrin-stabilizing factor (FSF) activity of blood plasma in healthy children. Z. Kinderheilk. 112 : activity of 142 (1972).

25. Roche, Basle, Switzerland.

26. Kindly supplied by Dr. Lars G. Nilsson, Department Organic Chemistry, Farmaceutiska Fakulteten, Stockholm, Sweden.

27. Novo Laboratories, Copenhagen, The Netherlands.

28. Professor Lorand is the recipient of a United States Public Health Service Career Award (5-K6-HE-3512).

29. In Malmö this work was supported by the Swedish Medical Research Council (B74-19X-87-10) and Riksbankens Jubileumsfond. At Northwestern University the research was supported by the National Institutes of Health (HL-02212 and HL-16346), and by Evanston Hospital.

30. Requests for reprints should be addressed to: Professor L. Lorand, Department of Biochemistry and Molecular Biology, Northwestern University, Evanston, I11. 60201 (USA).

31. Accepted for publication May 2, 1974. 